\title{
The Effect of Aluminum Exposure on Reproductive Ability in the Bank Vole (Myodes glareolus)
}

\author{
Agata Miska-Schramm $^{1}$ • Joanna Kapusta ${ }^{1}$ - Malgorzata Kruczek ${ }^{1}$
}

Received: 20 June 2016 / Accepted: 6 September 2016 / Published online: 29 September 2016

(C) The Author(s) 2016. This article is published with open access at Springerlink.com

\begin{abstract}
Human impact on the environment is steadily increasing the amounts of aluminum in the ecosystems. This element accumulates in plants and water, potentially exposing herbivores to its harmful effect. In heavily polluted sites, a decrease in the density of small rodent populations has been observed. This decline may be caused by many factors, including decreased fertility. The aim of the presented research was to determine how aluminum, administered at concentrations similar to those recorded in industrial districts (Al $\mathrm{I}=3 \mathrm{mg} / \mathrm{l}, \mathrm{Al} \mathrm{II}=200 \mathrm{mg} / \mathrm{l}$ ), affects the reproductive abilities of small rodents. As the indicators of reproductive abilities, body weight, weight of the testes and accessory sex glands of males, and uterus weight of females were estimated. In females, the number of matured follicles (types 6, 7, and 8) was analyzed, while in males, the quantity and quality (matured, viable, swollen, motile, head abnormalities) of epididymal sperm cells were assessed. Moreover, the development of testes, measured by spermatogenic index, was determined. The model species was the bank vole. Our results have proven that aluminum impairs adult individuals' reproductive abilities by decreasing the quality and quantity of sperm cells and by causing morphologically abnormal development of the gonads. However, no difference in male organometric parameters was found, and only in females treated with $3 \mathrm{mg} / \mathrm{l} \mathrm{Al}$, the uterus weight was higher than control. No differences were found in the total number of matured follicles. These results suggest that the decline in rodent numbers in industrial
\end{abstract}

Agata Miska-Schramm

agata.miska.schramm@gmail.com

1 Institute of Environmental Sciences, Jagiellonian University, Gronostajowa 7, 30-387 Kraków, Poland districts is due, at least in part, to poorer males' reproductive abilities, resulting from exposure to aluminum contamination.

Keywords Aluminum - Bank vole · Ovarian follicles · Spermatozoa $\cdot$ Sperm cells

\section{Introduction}

Soil contamination resulting in substantial concentrations of different pollutants, including metals, has been observed in plants [1], which then may be ingested by herbivores. In polluted sites, a decline in the density of rodent populations has been widely observed [2-4]. To date, there is no data published clarifying whether the decrease is due to increased mortality; other ecological processes, such as migration; or the altered reproductive abilities. The presented research addresses this question by testing the effects of aluminum on reproductive abilities of small rodents.

Aluminum has no known biological role in living organisms and may be classified as a toxic metal [5]. In vertebrates, this element may be deposited in different tissues, including the central nervous system, becoming a neurotoxin $[6,7]$. This element has long been implicated in the pathogenesis of Alzheimer's disease, but the precise mechanism of aluminum toxicity in this disease remains unknown [8]. Deposition can occur throughout the brain, as $\mathrm{Al}$ can cross the blood-brain barrier [9-11]. Disorders of steroidogenesis may arise through the deposition of $\mathrm{Al}$ in the hypothalamus and pituitary gland. However, the mechanisms of aluminum toxicity are not fully understood $[12,13]$.

Intraperitoneal administration of aluminum is known to decrease testosterone levels in the testes and plasma of mice, depending on the dose and duration of exposure: the reduction was much greater under treatment with a dose of $175 \mathrm{mg}$ 
$\mathrm{AlCl}_{3} / \mathrm{kg} / \mathrm{day}$ and then at $66 \mathrm{mg} \mathrm{AlCl}_{3} / \mathrm{kg} /$ day [14]. Aluminum also decreased mice serum testosterone levels and testicular and epididymal weight and significantly reduced testicular, spermatid, and epididymal sperm counts $[7$, $14,15]$. Aluminum accumulation in the testes has been correlated with necrosis of mice spermatids and spermatocytes, as well as reduced fertility [15]. A negative impact of aluminum on rabbit sperm cell motility and viability has been shown in vitro [16].

Knowledge of the effects of aluminum on the female reproductive system is limited. In female mice, Mohammed and collaborators [17] showed histopathological changes in the ovaries and decreased fertility, as measured by the number of pregnant females and the number of absorbed fetuses, after 12 weeks of aluminum chloride administration (dose range $1000-1400 \mathrm{mg} / \mathrm{kg}$ ). Fu and collaborators [18] noted a disruption of the rat ovary structure after 64,128 , and $256 \mathrm{mg} / \mathrm{kg}$ aluminum intake, while Trif and collaborators [19] reported significant lengthening of the sexual cycle in female rats after $0.2,0.4$, and $1 \mathrm{mg} / \mathrm{kg}$ aluminum sulfate administration in the uterus.

There are no data on the impact of aluminum doses, equivalent to the environmental levels of the metal, on the reproductive system.

Plants growing on contaminated soil may accumulate substantial concentrations of different metals which then often become ingested by herbivores [20]. For animals living in polluted areas, often the only sources of water are contaminated [21]. Significant concentrations of different metals have been found in the tissues of such animals [20, 22-28]. According to Zafar and collaborators' [29] research on laboratory rats, the first target of aluminum accumulation is bones and then the spleen, kidney, and liver. Aluminum is a chemical element abundant in the biosphere and widespread in the air (ca. $150 \mathrm{mg} / \mathrm{m}^{3}$ ), water (ca. $0.8 \mathrm{mg} / \mathrm{l}$ ), and plants (up to $200 \mathrm{mg} / \mathrm{kg}$ ) [30]. Kabata-Pendias [30] reported that exposure to $3 \mathrm{mg} / \mathrm{l}$ of aluminum did not disrupt the proper functioning of invertebrates' internal organs. On heavily polluted sites, plants, which are the rodent's food base, may accumulate up to $200 \mathrm{mg} / \mathrm{kg}$ aluminum from the atmosphere and water [1]; therefore, those two doses were chosen to be tested in our research. However, some species, adapted to acid soils, accumulate more than $10,000 \mathrm{mg} / \mathrm{kg} \mathrm{Al}[31,32]$. The more acidic the environment, the more $\mathrm{Al}$ is accumulated in the plant tissues [33].

The model species chosen for these experiments is the bank vole (Myodes glareolus, Schreber 1780). It is the most common rodent species in Europe and Asia. Bank vole is an animal living mostly in mixed forests with rich undergrowth, thickets, meadows, and forest gaps [34-36] and foraging often in fields [37]. For many years, the bank vole was considered a polygynous species [38], but molecular techniques have revealed that females commonly mate with multiple males [39,
40] and, therefore, should be considered promiscuous. In the wild, bank vole reproductive season starts in April and lasts through late September [41]. In standard laboratory conditions, it reproduces all year long. Females give birth to one to eight pups, pregnancy lasts 18-19 days, and lactation occurs from 18 days up to 3 weeks [41]. Moreover, in the wild, it may be found in many of the contaminated areas [42]. As a small rodent, it is particularly useful as a bioindicator, which has been proven in a number of studies [24, 25, 43, 44]. Moreover, our own breeding colony originated from the wild and its reproductive biology has been very well described (for example: [45-48]). Those attributes make it a perfect model species for the presented research.

To determine the impact of aluminum on the reproductive abilities of sexually mature bank vole males, body weight and the weight of the testes and accessory sex glands were compared between animals treated with aluminum solutions and those provided with water. The quantity and quality of epididymal sperm and spermatogenic activity were also assessed. Sexually mature females' reproductive abilities were assessed based on their body weight and uterus weight. Also, the number and type of mature follicles in females from the experimental groups were analyzed from histological slides of ovaries.

\section{Material and Methods}

\section{Animals and Housing Conditions}

The bank voles (M. glareolus, Schreber 1780) came from the laboratory colony of the Institute of Environmental Sciences, Jagiellonian University, Krakow. The original stock was obtained in 1976 from the Mammalian Research Institute of the Polish Academy of Sciences (Białowieża) and is maintained as an outbred stock colony according to the system described by Green [49]. Briefly, each generation consists of at least 22 breeding pairs; the male and female of each mating pair do not share parents or grandparents. This breeding system ensures the heterogeneity of the colony [49]. The animals were housed in polyethylene cages $(40 \mathrm{~cm} \times 25 \mathrm{~cm} \times 15 \mathrm{~cm})$ under a 14 -h photoperiod (7 am-9 pm light, 9 pm-7 am dark) at $21 \pm 1{ }^{\circ} \mathrm{C}$ and $60 \%$ humidity. Wood shavings were provided as a bedding material and changed once a week. Standard pelleted chow for laboratory rodents (Labofeed H, Kcynia) and liquid in the form of deionized water or solutions of aluminum were available ad libitum.

For the study, at 19-20 days of age, the weanlings were separated from their parents and placed in clean cages. At 4 weeks of age, three to five individuals were placed in the same-sex cages. Then, both females and males were randomly divided into three experimental groups. Starting from 4 weeks 
of age, for 12 weeks, the animals were treated with different metal solutions or given deionized water.

\section{Experimental Groups}

The control (C) group was provided with deionized water, Al I $(3 \mathrm{mg} / \mathrm{l} \mathrm{dose})$-aluminum chloride(VI) hexahydrate $\left(\mathrm{AlCl}_{3}\right.$. $\left.6 \mathrm{H}_{2} \mathrm{O}\right)$ (AR purity grade, Avantor, Poland) at a concentration of $3 \mathrm{mg} \mathrm{Al}{ }^{3+} / 1$ (1.5 $\mathrm{mg} \mathrm{Al}^{3+} / \mathrm{kg}$ body mass/day), and $\mathrm{Al} \mathrm{II}$ $\left(200 \mathrm{mg} / \mathrm{l}\right.$ dose)-aluminum chloride(VI) hexahydrate $\left(\mathrm{AlCl}_{3}\right.$. $\left.6 \mathrm{H}_{2} \mathrm{O}\right)$ (AR purity grade, Avantor, Poland) at a concentration of $200 \mathrm{mg} \mathrm{Al}^{3+} / 1$ (100 $\mathrm{mg} \mathrm{Al}^{3+} / \mathrm{kg}$ body mass/day).

\section{Reproductive Activity of Adults}

\section{Males}

\section{Organometric Parameters}

After cervical dislocation, 12 males from each experimental group, at 16 weeks of age, were weighed, and the paired testes, seminal vesicles, and coagulation glands were dissected out and weighed (the latter two together). Testes were placed in a fixative. Semen was collected for further analysis as described below.

\section{Epididymal Sperm Evaluation}

Preparation of Epididymal Sperm Suspension After applying gentle pressure to each cauda epididymis with forceps, allowing epididymal sperm to pass to the vasa deferentia, the content of the latter was suspended in a $100 \mu \mathrm{l}$ M2 medium (Sigma-Aldrich, Germany) and allowed to disperse for 2 min.

Epididymal Sperm Suspensions and Concentration A 1:20 dilution of epididymal sperm suspension with the M2 medium was prepared, and the number of live sperm cells in 100 squares of a hemocytometer (Bürker chamber) was counted under a light microscope at $\times 400$. A cover slip was placed on the sample to restrict sperm cell movement.

Epididymal Sperm Motility Sperm cell motility was assessed in a hemocytometer. The proportion of motile sperm - sperm showing a progressive movement among 100 counted sperm cells - was recorded.

\section{Epididymal Sperm Tail Membrane Integrity-Water Test} The integrity of the epididymal sperm tail membrane was determined in hypoosmotic swelling tests; $20 \mu \mathrm{l}$ of epididymal sperm suspension was mixed with $120 \mu$ d distilled water on a clean glass slide. Then, the mixture was gently covered with a cover slip and incubated for $5 \mathrm{~min}$ at $37^{\circ} \mathrm{C}$ before being examined [32]. The proportion of sperm cells showing swelling, among 100 counted sperm cells from each male, was recorded and classified as follows: swollen (sperm cells with loop on tail) and not swollen (sperm cells with straight or gently bent tail).

Epididymal Sperm Viability-Eosin-Y Test The test reflects the structural and morphological integrity of the sperm membrane [50]. To assess sperm viability, $20 \mu$ of epididymal sperm suspension was mixed with $20 \mu \mathrm{l}$ of $0.2 \%$ eosin-Y, incubated for $10 \mathrm{~min}$ at $37{ }^{\circ} \mathrm{C}$, and smeared on a slide. The proportion of cells, with unstained heads (viable sperm cells) among 100 counted cells, was recorded.

Epididymal Sperm Cells Without a Cytoplasmic Droplet In this procedure, $20 \mu \mathrm{l}$ of epididymal sperm suspension was transferred to a slide and gently covered with a cover slip. The percentage of spermatozoa with a cytoplasmic droplet among 100 counted spermatozoa showing a progressive movement was recorded [50].

Epididymal Sperm Morphology For morphological examination, a small drop of epididymal sperm suspension was smeared on a slide, air-dried, fixed in acetic alcohol (absolute alcohol/glacial acetic acid, 3:1), dehydrated in ethanol series, and stained with Papanicolaou to determine the proportions of different sperm head anomalies.

Head anomalies were classified as follows: normal (sperm with proper head morphology), class 1 (lack of the top part of the hook and anomalies in the base of head), and class 2 (lack of the hook as well as serious anomalies in the proximal part of the sperm head, with possible changes in base the of head) [32].

All above procedures were performed twice, and the mean was calculated for each individual [50].

\section{Spermatogenic Index}

Isolated testes were fixed in formalin, dehydrated in an ethanol series, infiltrated and embedded in paraffin, cut into $7-\mu \mathrm{m}$ thick cross sections, and then stained with hematoxylin and eosin and classified with light microscopy as to functional state according to the spermatogenic index [51, 52]. The spermatogenic index (SI), with values from 5 to 0 , gives a measure of the seminiferous epithelium activity, with 5 representing complete spermatogenesis with abundant sperm production and 0 representing the presence of only Sertoli cells and spermatogonia; values from 1 to 4 represent incremental changes of spermatogenesis: 
IS $=0$ - The tubules are very small and contain only Sertoli cells and spermatogonia. A few spermatocytes are visible.

IS $=1-$ There are small tubules containing only Sertoli cells, spermatogonia, and primary spermatocytes. The interstitial cell patches are very small, and most of the cell nuclei are no longer round.

IS $=2-$ No elongated spermatids are present, but round spermatids still occur. Some interstitial nuclei are no longer round.

IS $=3$ - There is a further reduction in the number of sperm cells and spermatids. The interstitial cell patches are much smaller, but the nuclei are still round.

IS = 4-Spermatogenesis is complete, but elongated spermatids and sperm cells are less abundant. The interstitial cell patches are slightly smaller.

IS $=5$ - The seminiferous tubules are large, and spermatogenesis is complete. The interstitial cell patches are very large, and the cell nuclei are round.

The average of two groups of ten seminiferous tubules situated in the center of the testicular cross section was taken as the spermatogenic index estimate.

\section{Females}

\section{Organometric Parameters}

After cervical dislocation, 12 females from each experimental group, at 16 weeks of age, were weighed, after which the uterus was removed and weighed. Ovaries were also dissected and placed in a fixative for further analysis.

\section{Ovarian Follicle Assessment}

Isolated ovaries were fixed in Boinea's solution, dehydrated in an ethanol series, infiltrated and embedded in paraffin, cut into 6 - $\mu$ m-thick cross sections, and then stained with hematoxylin and eosin and analyzed under a light microscope to classify the different stages. The follicles in ovaries from the females in all experimental groups were classified as type 6 (diameter 355.06-417.99 $\mu \mathrm{m}$ ), type 7 (diameter 526.58-594.67 $\mu \mathrm{m}$ ), or type 8 (diameter $715.78-867.39 \mu \mathrm{m}$ ) according to Pedersen and Peters [53]. Follicle diameter was determined using ImageJ 1.48k (National Institutes of Health, USA) software. The sum of each type of follicle, in an individual, was recorded.

\section{Statistical Analysis}

The following statistical tests were used to analyze the data: one-way ANOVA for morphological parameters, sperm cell parameters, spermatogenic index, and number and type of ovarian follicles, and post hoc Tukey's test following oneway ANOVA to test the significance of differences between means.

All procedures employed STATISTICA v. 10. All data are presented as means \pm SE. The level of statistical significance was deemed to be $p<0.05$.

\section{Results}

\section{Male Organometric Parameters and Sperm Evaluation}

\section{Organometric Parameters}

The results summarized in Table 1 show that aluminum did not affect the morphological parameters of adult males. There were no significant differences in body weight $(\mathrm{g})$ between control and Al I males, between control and Al II males, or between $\mathrm{Al}$ I and Al II males $(p=0.38$, NS) $(\mathrm{NS}=$ not significant). Similarly, weight of the testes ( $p=0.7, \mathrm{NS})$ and accessory sex gland (mg; $p=0.28$, NS) did not significantly differ between control and $\mathrm{Al} \mathrm{I}$ males, between control and $\mathrm{Al}$ II males, or between $\mathrm{Al}$ I and $\mathrm{Al}$ II males.

\section{Epididymal Sperm Evaluation}

As shown in Figs. 1 and 2, exposure to aluminum lowered sperm quantity and quality. Sperm counts were significantly lower in males treated with 200 and $3 \mathrm{mg} / \mathrm{l} \mathrm{Al}$ than in control males. There were no significant differences in sperm count between $\mathrm{Al}$ I and $\mathrm{Al}$ II males ( $p=0.39, \mathrm{NS})$. The proportion of motile sperm cells was lower in Al II males than in both the control and Al I animals. Al I males also had a lower proportion of motile sperm cells than control males $(p<0.01)$. The proportion of swollen sperm cells was lower in Al II males than in both the control and Al I males, but there were no differences in the proportion of swollen sperm cells between control and Al I males ( $p=0.14$, NS). As shown in Fig. 2 , the proportion of viable sperm cells was lower in Al II males than in control and $\mathrm{Al} \mathrm{I}$ males. Males from the $\mathrm{Al}$ I group had also a lower proportion of viable sperm cells than control individuals $(p<0.01)$. There were no differences in the proportion of mature sperm cells without a droplet between males from the control, Al I, and Al II groups ( $p=0.42$, NS; Fig. 2). As presented in Table 2, Al II males had a significantly higher proportion of abnormal sperm heads than both the control and Al I males $(p<0.01)$. There were no differences in the total proportion of abnormal sperm heads between males given deionized water and those receiving $3 \mathrm{mg} / \mathrm{l}$ aluminum $(p=0.11$, NS; Table 2). There were significant differences in the proportions of both classes of abnormal sperm heads between males from all experimental groups (Table 2). The proportion of class 1 abnormal sperm heads was the highest in 
Table 1 Organometric parameters of bank vole males treated with two aluminum solutions ( $\mathrm{Al} \mathrm{I}=3 \mathrm{mg} / \mathrm{l}$ and $\mathrm{Al}$ $(\mathrm{C}=0 \mathrm{mg} / \mathrm{l})$ $\mathrm{II}=200 \mathrm{mg} / \mathrm{l})$ or deionized water

\begin{tabular}{lccccc}
\hline & \multicolumn{2}{l}{ Experimental group } & & \\
\cline { 2 - 6 } & $\mathrm{C}$ & $\mathrm{Al}$ & $\mathrm{Al}$ & $F_{(2,33)}$ & $p$ \\
\hline Body wt (g) & $27.5 \pm 1.1$ & $28.3 \pm 1.2$ & $29.7 \pm 1.1$ & 1.01 & $\mathrm{NS}$ \\
Testes wt (mg) & $763.2 \pm 33.4$ & $780.4 \pm 18.7$ & $795.6 \pm 27.2$ & 0.36 & $\mathrm{NS}$ \\
Accessory sex gland wt (mg) & $351.9 \pm 25.1$ & $362.8 \pm 25.2$ & $412.8 \pm 33.1$ & 1.34 & $\mathrm{NS}$ \\
\hline
\end{tabular}

Means \pm SE

$\mathrm{Al}$ II males and higher in control and Al I animals, and the same relations were found for the proportion of class 2 abnormal sperm heads $(p<0.01)$. There were no significant differences in the proportion of class $1(p=0.13, \mathrm{NS})$ as well as class $2(p=0.1, \mathrm{NS})$ abnormal sperm heads between males from the control and $\mathrm{Al} 1$ groups.

\section{Spermatogenic Index}

The highest dose of aluminum ( $200 \mathrm{mg} / \mathrm{l}$, Al II) had a negative effect on spermatogenesis stage as measured by the spermatogenic index (Table 2). Al II animals had a lower spermatogenic index than both control and Al I males $(p<0.01)$. The spermatogenic index of control and $\mathrm{Al}$ I males did not differ significantly $(p=0.07, \mathrm{NS})$.

\section{Female Organometric Parameters and Ovarian Follicle Evaluation}

\section{Organometric Parameters}

As shown in Table 3, there were no differences in body weight (g) between control and $\mathrm{Al} \mathrm{I}$ females, between control and $\mathrm{Al}$ II females, or between Al I and Al II females ( $p=0.89$, NS). Al I females had a higher uterus weight (mg) than control individuals $(p<0.05)$. There were no differences in uterus

\section{sperm count}

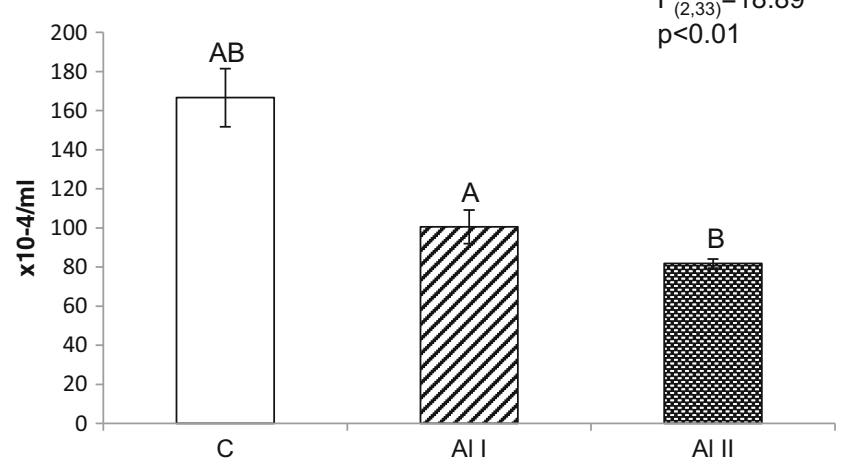

Fig. 1 Sperm counts of adult bank vole males treated with two aluminum solutions $(A l I=3 \mathrm{mg} / 1$ and $A l I I=200 \mathrm{mg} / \mathrm{l})$ or deionized water $(C=0 \mathrm{mg} / \mathrm{l})$. Means bearing the same letter differ significantly; $A, B$ $p<0.01$. Means $\pm \mathrm{SE}$ weight between control and Al II females ( $p=0.17$, NS) or between $\mathrm{Al}$ I and $\mathrm{Al}$ II females $(p=0.38$, NS).

\section{Ovarian Follicle Evaluation}

As seen in Table 4, there were no differences in the total number of ovarian follicles (sum of types 6, 7, and 8) between the females from all experimental groups $(p=0.48, \mathrm{NS})$. The same was true for follicle types $6(p=0.44, \mathrm{NS})$ and $8(p=0.45$, NS) which were analyzed separately. The number of type 7 follicles was higher only in $\mathrm{Al}$ I than in $\mathrm{Al}$ II females $(p<0.01)$; there were no significant differences in the proportion of type 7 follicles between control and Al I females ( $p=0.07$, NS) or between control and $\mathrm{Al}$ II females $(p=0.52, \mathrm{NS})$.
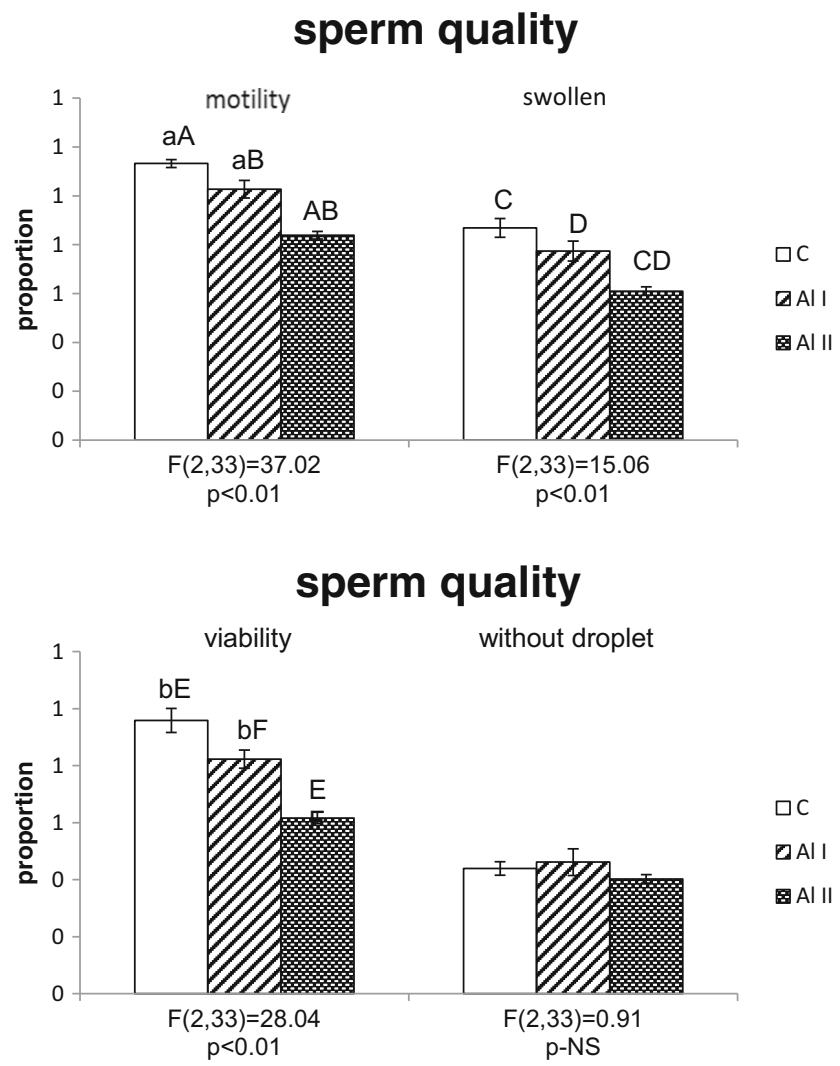

Fig. 2 Proportion of swollen, viable, motile, and dropletless sperm cells from bank vole males treated with two aluminum solutions ( $A l I=3 \mathrm{mg} / 1$ and $A l I I=200 \mathrm{mg} / \mathrm{l})$ or deionized water $(C=0 \mathrm{mg} / \mathrm{l})$. Means bearing the same letter differ significantly; $A-F p<0.01 ; a, b p<0.05$. Means $\pm \mathrm{SE}$ 
Table 2 Proportion of sperm cell head abnormalities and spermatogenic index in bank vole males treated with two aluminum solutions (Al I = $3 \mathrm{mg} / \mathrm{l}$ and $\mathrm{Al}$ $\mathrm{II}=200 \mathrm{mg} / \mathrm{l})$ or deionized water $(\mathrm{C}=0 \mathrm{mg} / \mathrm{l})$

\begin{tabular}{lcccrc}
\hline \multicolumn{7}{l}{ Experimental group } \\
\cline { 2 - 6 } & $\mathrm{C}$ & $\mathrm{A} 1 \mathrm{I}$ & $\mathrm{A} 1 \mathrm{II}$ & $F_{(2,33)}$ & $p$ \\
\hline Total abnormalities & $0.22^{\mathrm{A}} \pm 0.01$ & $0.29^{\mathrm{B}} \pm 0.03$ & $0.43^{\mathrm{AB}} \pm 0.03$ & 17.77 & $<0.01$ \\
Class 1 & $0.13^{\mathrm{A}} \pm 0.02$ & $0.19^{\mathrm{a}} \pm 0.02$ & $0.28^{\mathrm{Aa}} \pm 0.02$ & 12.82 & $<0.01$ \\
Class 2 & $0.15^{\mathrm{A}} \pm 0.02$ & $0.21^{\mathrm{B}} \pm 0.03$ & $0.32^{\mathrm{AB}} \pm 0.02$ & 15.23 & $<0.01$ \\
Spermatogenic index & $4.8^{\mathrm{A}} \pm 0.1$ & $4.6^{\mathrm{B}} \pm 0.0$ & $3.7^{\mathrm{AB}} \pm 0.0$ & 216.54 & $<0.01$ \\
\hline
\end{tabular}

Means bearing the same letter differ significantly; means $\pm \mathrm{SE}$

A,B $p<0.01 ;{ }^{\mathrm{a}} p<0.05$

\section{Discussion}

In male bank vole, aluminum ingestion did not affect body weight or any other tested morphological parameter. The literature reports various findings on the effects of aluminum on the reproductive parameters of males of different species. Exposure to aluminum within a concentration range of 3$200 \mathrm{mg} / \mathrm{l} \mathrm{seems} \mathrm{to} \mathrm{have} \mathrm{no} \mathrm{effect} \mathrm{on} \mathrm{the} \mathrm{body,} \mathrm{testes,} \mathrm{and}$ epididymal weights of other adult rodents [54]. Only much higher aluminum concentrations significantly reduced the weight of those organs in mice [55] and rats [56]. These can be explained by the finding that aluminum concentrations higher than $200 \mathrm{mg} / \mathrm{l}$ are correlated with lower levels of testosterone [57, 58], the main androgen controlling reproductive tissue development in males.

We did not find any effect of aluminum on male reproductive organ weights but did show a decline of spermatogenic activity (SI) inversely proportional to the aluminum concentration. Other researchers have found similar effects of aluminum in mice [59] and rats [60,61]. Seminiferous epithelium activity is a key factor in spermatogenesis [62] and, along with sperm count and sperm quality, is crucial to the successful fertilization. Sperm quality and quantity, as assessed by its motility, sperm tail morphology, viability, and head abnormalities, were curtailed by aluminum in our experiment. Only sperm maturation, measured as the proportion of sperm cells without a cytoplasmic droplet, was not affected by the aluminum ingestion, probably because the aluminum does not affect the morphology of the epididymis, where final sperm

Table 3 Organometric parameters of bank vole females treated with two aluminum solutions ( $\mathrm{Al} \mathrm{I}=3 \mathrm{mg} / \mathrm{l}$ and $\mathrm{Al} \mathrm{II}=200 \mathrm{mg} / \mathrm{l}$ ) or deionized water $(\mathrm{C}=0 \mathrm{mg} / \mathrm{l})$

\begin{tabular}{|c|c|c|c|c|c|}
\hline & \multicolumn{5}{|c|}{ Experimental group } \\
\hline & $=$ & $\mathrm{Al} \mathrm{I}$ & Al II & $F_{(2,33)}$ & $p$ \\
\hline Body wt (g) & $23.5 \pm 1.1$ & $21.9 \pm 1.0$ & $21.9 \pm 0.6$ & 0.36 & NS \\
\hline Uterus wt (mg) & $63.8^{\mathrm{a}} \pm 10.2$ & $99^{\mathrm{a}} \pm 6.3$ & $79.4 \pm 8.0$ & 0.02 & $<0.05$ \\
\hline
\end{tabular}

Means bearing the same letter differ significantly; means $\pm \mathrm{SE}$

${ }^{\mathrm{a}} p<0.05$ maturation takes place $[62,63]$. However, under $\mathrm{Al}$ exposure, sperm cells with abnormal head morphology were produced, and this process also takes place and is regulated in the epididymis [64]. Lower sperm counts and altered sperm parameters under aluminum exposure have also been found in humans [65, 66], rats [54], and rabbits [16, 67]. Sun and collaborators [58] found lower testosterone levels in male rats exposed to $256.72 \mathrm{mg} / \mathrm{kg} \mathrm{Al}$, so it is possible that testosterone disorders occurred in the $200 \mathrm{mg} / 1 \mathrm{Al}$ treatment. Spermatogenic activity, spermatogenesis, and spermiogenesis are mainly under the control of testosterone [68]. Their negative effect on SI, sperm quality, and quantity may be explained by the effect of $200 \mathrm{mg} / \mathrm{l}$ dose, disturbing testosterone homeostasis, but two other mechanisms may also play a role. Guo and colleagues [69]suggested that aluminum induces production of nitrogen monoxide (NO), a suppressor of circulating and testicular testosterone. Alternatively, Zhu and collaborators [70] suggested that the main reason for reduced spermatogenesis in male rats was a decline in testicular enzyme activity and an imbalance in the concentrations of other trace elements $(\mathrm{Zn}, \mathrm{Fe}, \mathrm{Cu})$ in the testes. Further investigations should shed more light on those mechanisms.

Aluminum is a non-physiological element considered to be a potent neurotoxicant [71]. It can cross the blood-brain barrier and may be deposited in brain tissue [9-11]. It deposits in most areas of the brain (the cerebellum, ventral midbrain, cortex, hippocampus, and striatum), depending on the form

Table 4 Number of ovarian follicles in bank vole females treated with two aluminum solutions ( $\mathrm{Al} \mathrm{I}=3 \mathrm{mg} / \mathrm{l}$ and $\mathrm{Al} \mathrm{II}=200 \mathrm{mg} / \mathrm{l}$ ) or deionized water $(\mathrm{C}=0 \mathrm{mg} / \mathrm{l})$

\section{Experimental group}

\begin{tabular}{lrrrll} 
& \multicolumn{1}{l}{ C } & \multicolumn{1}{c}{ Al I } & \multicolumn{1}{l}{ Al II } & $F_{(2,33)}$ & $p$ \\
\hline Total & $12.8 \pm 1.6$ & $14.3 \pm 1.5$ & $11.9 \pm 0.9$ & 0.76 & NS \\
Type 6 & $5.0 \pm 0.9$ & $5.0 \pm 0.9$ & $5.1 \pm 0.9$ & 0.83 & NS \\
Type 7 & $3.6 \pm 0.6$ & $5.5^{\mathrm{A}} \pm 0.7$ & $2.7^{\mathrm{A}} \pm 0.5$ & 6.06 & $<0.01$ \\
Type 8 & $4.2 \pm 0.8$ & $3.8 \pm 0.7$ & $2.9 \pm 0.7$ & 0.81 & NS \\
\hline
\end{tabular}

Means bearing the same letter differ significantly; means $\pm \mathrm{SE}$

${ }^{\mathrm{A}} p<0.01$ 
of exposure: a greater and more significant increase was noted in the group of rats receiving aluminum via an intraperitoneal administration, then in rats receiving aluminum via an oral administration [9, 72, 73]. The neurodegenerative effects of the intracisternal injection of $\mathrm{Al}$ included the formation of intraneuronal neurofilamentous aggregates, oxidative stress, and apoptosis [74]. Verstraeten and collaborators [75] in their review about $\mathrm{Al}$ and molecular mechanisms of brain toxicity, indicated that $\mathrm{Al}$ neurotoxicity is not caused by a single alteration, but it is a result of adverse effects at multiple cellular levels. Barabasz and collaborators [76] suggested that neurotoxic effects of aluminum result in the displacement of magnesium ions in ATP, which causes changes in the functioning of all enzymes utilizing ATP as a substrate. Aluminum may also play a role on the hormonal level, by interfering with some of the neurohormonal pathways, like the serotonin system [77].

Aluminum's influence on the brain tissue potentially may also play a role in the interruption of reproductive processes [78]. Our experiments showed almost no influence of aluminum on adult females' reproductive abilities. Females treated with $3 \mathrm{mg} / \mathrm{l} \mathrm{Al}$ had an increase of uterus weight as compared to control females. That increase was accompanied by an increased number of type 7 ovarian follicles in the females treated with $3 \mathrm{mg} / \mathrm{l} \mathrm{Al}$. Research on adult rat females employing aluminum doses three and six times smaller than our lower dose showed no effect of aluminum on body and uterus weights $[79,80]$. Much higher Al concentrations (1000$1400 \mathrm{mg} / \mathrm{kg}$ ) reduced female body weight, reduced absolute uterus weight, and caused histological changes in ovarian sections [17]. It may be that the concentrations we applied, which are near-normal, though at levels found in polluted districts, were too low to cause significant ovarian disorders. However, this assumption would not be coherent with overall obtained result. Both sexes were exposed to the same aluminum concentration, but in males, the damage caused by aluminum on the reproductive system is more visible than that in females. This sex-specific difference may lay in the detoxification systems.

The liver is considered to be the main detoxification target organ. It is characterized by sexually dimorphic gene expression translating into sex-specific differences in xenobiotic, for example aluminum and metabolism, with distinct responses of males and females to environmental challenges [81, 82]. In mice, examples of sex-dependent genes include the malepredominant cytochrome P450 Cyp2d9, which encodes testosterone 16-a-hydroxylase inactivating the main male sex hormone, and the female-predominant Cyp2a and Сyp2b genes involved in xenobiotic metabolism [82]. Kalthoff and collaborators [83] indicated that transcriptional regulation of human uridine diphosphate glucuronosyltransferase genes (UGT1A), important hepatogastrointestinal detoxification enzymes for xenobiotics, is also gender-specific. In response to environmental challenges, on a molecular level, males display a higher predisposition than females for liver abnormalities [84, 85]. Therefore, liver handicap in males may result in a more rapid reproductive biology decline caused by aluminum intoxication. Moreover, Gómez and collaborators [86] have proven that tissue $\mathrm{Al}$ retention patterns may be significantly altered and are also depending on the age at which $\mathrm{Al}$ exposure occurs.

A properly functioning reproductive system and welldeveloped reproductive organs are not the only key ingredients of reproductive success; sexual behavior is important as well. Aluminum concentrations, similar to those applied in our experiments, are correlated with changes in non-reproductive rodent behavior [87-90]; it is reasonable to suggest that aluminum may also modify sexual behavior. Indeed, Abu-Taweel and collaborators [57] found a significant decrease of social contacts and sexual behavior after aluminum application, but they used higher doses (300 and $600 \mathrm{mg} / \mathrm{kg}$ ) than those in our experiment. Our pilot behavioral research did not indicate changes in rodent sexual behavior under aluminum exposure, except for fewer aggressive approaches, in a preference test by females to males treated with $200 \mathrm{mg} / \mathrm{l} \mathrm{Al}$ than, to control males. Because the aggressiveness is considered a part of bank vole sexual behavior [91] and might be correlated with an aluminum-induced decrease of libido [16], more behavioral research in this field should be performed. Additionally, to extrapolate the obtained results into a natural environment, it would be required to run similar types of measurements on wild-caught voles from Alpolluted sites and to couple such measurements with population studies, to determine whether there are effects on reproductive success and juvenile recruitment into the population.

\section{Compliance with Ethical Standards}

Funding This study was funded by grants from the Jagiellonian University (grant number: DS/MND/WBiNoZ/INoS/22/2013).

Conflict of Interest The authors declare that they have no conflict of interest.

Ethical Approval All applicable international, national, and/or institutional guidelines for the care and use of animals were followed (with approval of the Regional Committee on Animal Experimentation in Krakow; protocol no. 36/2009).

Open Access This article is distributed under the terms of the Creative Commons Attribution 4.0 International License (http:// creativecommons.org/licenses/by/4.0/), which permits unrestricted use, distribution, and reproduction in any medium, provided you give appropriate credit to the original author(s) and the source, provide a link to the Creative Commons license, and indicate if changes were made. 


\section{References}

1. Kucharczak E, Moryl A (2010) Contents of metals in cultivated plants in Zgorzelec-Bogatynia region. Part 1. Lead, cadmium, aluminium. Environ 42:52-61

2. Kataev GD, Suomela J, Palokangas P (1994) Densities of microtine rodents along a pollution gradient from a copper-nickel smelter. Oecol 97(4):491-498. doi:10.1007/BF00325887

3. Sheffield SR, Sawicka-Kapusta K, Cohen JB, Rattner BA (2001) Rodentia and lagomorpha. In: Shore RF, Rattner BA (eds) Ecotoxicology of wild mammals. John Wiley \& Sons, Ltd, New York

4. Cornulier T, Yoccoz NG, Bretagnolle V, Brommer JE, Butet A, Ecke F, Elston DA, Framstad E, Henttonen H, Hörnfeldt B, Huitu O, Imholt C, Ims RA, Jacob J, Jędrzejewska B, Millon A, Petty SJ, Pietiäinen H, Tkadlec E, Zub K, Lambin X (2013) Europe-wide dampening of population cycles in keystone herbivores. Science 340(6128):63-66. doi:10.1126/science.1228992

5. Rajeswari TR, Sailaja N (2014) Impact of heavy metals on environmental pollution. J Chem Parmacol Sci 3:175-181

6. Bishop NJ, Morley R, Day JP, Lucas A (1997) Aluminum neurotoxicity in preterm infants receiving intravenousfeeding solutions. N Engl J Med 336(22):1557-1561. doi:10.1056/nejm199705293362203

7. Walton JR (2007) A longitudinal study of rats chronically exposed to aluminum at human dietary levels. Neurosci Lett 412(1):29-33. doi:10.1016/j.neulet.2006.08.093

8. Gupta VB, Anitha S, Hegde ML, Zecca L, Garruto RM, Ravid R, Shankar SK, Stein R, Shanmugavelu P, Jagannatha Rao KS (2005) Aluminium in Alzheimer's disease: are we still at a crossroad? Cell Mol Life Sci 62(2):143-158. doi:10.1007/s00018-004-4317-3

9. Sanchez-Iglesias S, Soto-Otero R, Iglesias-Gonzalez J, BarcielaAlonso MC, Bermejo-Barrera P, Mendez-Alvarez E (2007) Analysis of brain regional distribution of aluminium in rats via oral and intraperitoneal administration. J Trace Elem Med Biol 21(Suppl 1):31-34. doi:10.1016/j.jtemb.2007.09.010

10. Roig JL, Fuentes S, Teresa Colomina M, Vicens P, Domingo JL (2006) Aluminum, restraint stress and aging: behavioral effects in rats after 1 and 2 years of aluminum exposure. Toxicol 218(2-3): 112-124. doi:10.1016/j.tox.2005.10.006

11. Domingo JL, Llorens J, Sanchez DJ, Gomez M, Llobet JM, Corbella J (1996) Age-related effects of aluminum ingestion on brain aluminum accumulation and behavior in rats. Life Sci 58(17):1387-1395. doi:10.1016/0024-3205(96)00108-7

12. Yokel RA, Rhineheimer SS, Sharma P, Elmore D, McNamara PJ (2001) Entry, half-life, and desferrioxamine-accelerated clearance of brain aluminum after a single (26)Al exposure. Toxicol Sci 64(1):77-82

13. Krewski D, Yokel RA, Nieboer E, Borchelt D, Cohen J, Harry J, Kacew S, Lindsay J, Mahfouz AM, Rondeau V (2007) Human health risk assessment for aluminium, aluminium oxide, and aluminium hydroxide. J Toxicol Environ Health B Crit Rev 10(Suppl 1):1-269. doi:10.1080/10937400701597766

14. Guo C, Huang C, Chen S, Wang Hsu G (2001) Serum and testicular testosterone and nitric oxide products in aluminum-treated mice. Environ Toxicol Pharmacol 10(1-2):53-60. doi:10.1016/S13826689(01)00069-2

15. Llobet JM, Colomina MT, Sirvent JJ, Domingo JL, Corbella J (1995) Reproductive toxicology of aluminum in male mice. Fundam Appl Toxicol 25(1):45-51

16. Yousef MI, El-Morsy AM, Hassan MS (2005) Aluminium-induced deterioration in reproductive performance and seminal plasma biochemistry of male rabbits: protective role of ascorbic acid. Toxicology 215(1-2):97-107. doi:10.1016/j.tox.2005.06.025
17. Mohammed A, Mayyas I, Elbetieha A, Shoter A, Khamas W, Elnasser Z (2008) Toxicity evaluation of aluminium chloride on adult female mice. J Anim Vet Adv 7:552-556

18. Fu Y, Jia FB, Wang J, Song M, Liu SM, Li YF, Liu SZ, QW B (2014) Effects of sub-chronic aluminum chloride exposure on rat ovaries. Life Sci 100(1):61-66. doi:10.1016/j.lfs.2014.01.081

19. Trif A, Muselin F, RArgherie D, Dumitrescu E, Macinic I (2007) The consequences of chronic exposure to aluminium on some morphological biomarkers of reproductive function (body, genital organs, sexual accessory glands weight, seminiferous tubules diameter) in male rats. Luc Stin Med Vet 10:652-658

20. Wijnhoven S, Leuven RS, van der Velde G, Jungheim G, Koelemij EI, de Vries FT, Eijsackers HJ, Smits AJ (2007) Heavy-metal concentrations in small mammals from a diffusely polluted floodplain: importance of species- and location-specific characteristics. Arch Environ Contam Toxicol 52(4):603-613. doi:10.1007/s00244006-0124-1

21. Youngers PL, Banwart SA, Hedin RS (2002) Mine water; hydrology, pollution, remediation. Kluwer Academic, The Netherlands

22. Gdula-Argasinska J, Appleton J, Sawicka-Kapusta K, Spence B (2004) Further investigation of the heavy metal content of the teeth of the bank vole as an exposure indicator of environmental pollution in Poland. Environ Pollut 131(1):71-79. doi:10.1016/j. envpol.2004.02.025

23. Nikolov IG, Joki N, Vicca S, Patey N, Auchère D, Benchitrit J, Flinois JP, Ziol M, Beaune P, Drüeke TB, Lacour B (2010) Tissue accumulation of lanthanum as compared to aluminum in rats with chronic renal failure - possible harmful effects after long-term exposure. Nephron Exp Nephrol 115(4):e112-e121. doi:10.1159 /000313492

24. Martiniakova M, Omelka R, Jancova A, Formicki G, Stawarz R, Bauerova M (2012) Accumulation of risk elements in kidney, liver, testis, uterus and bone of free-living wild rodents from a polluted area in Slovakia. J Environ Sci Health A 47(9):1202-1206. doi:10.1080/10934529.2012.672062

25. Martiniakova M, Omelka R, Jancova A, Stawarz R, Formicki G (2011) Concentrations of selected heavy metals in bones and femoral bone structure of bank (Myodes glareolus) and common (Microtus arvalis) voles from different polluted biotopes in Slovakia. Arch Environ Contam Toxicol 60(3):524-532. doi:10.1007/s00244-010-9545-y

26. Ullah K, Hashmi MZ, Malik RN (2014) Heavy-metal levels in feathers of cattle egret and their surrounding environment: a case of the Punjab Province, Pakistan. Arch Environ Contam Toxicol 66(1):139-153. doi:10.1007/s00244-013-9939-8

27. Zounkova R, Jalova V, Janisova M, Ocelka T, Jurcikova J, Halirova J, Giesy JP, Hilscherova K (2014) In situ effects of urban river pollution on the mudsnail Potamopyrgus antipodarum as part of an integrated assessment. Aquat Toxicol 150:83-92. doi:10.1016/j. aquatox.2014.02.021

28. Badora A (2002) Bioaccumulation of $\mathrm{Al}, \mathrm{Mn}, \mathrm{Zn}$ and $\mathrm{Cd}$ in pea plants (Pisum sativum L.) against a background of unconventional binding agents. Pol J Environ Stud 11(2):109-116

29. Zafar TA, Weaver CM, Martin BR, Flarend R, Elmore D (1997) Aluminum (26Al) metabolism in rats. Exp Biol Med 216(1):81-85. doi:10.3181/00379727-216-44159

30. Kabata-Pendias A (2011) Trace elements in soils and plants, 4th edn. CRC, Taylor \& Francis Group, Boca Raton

31. Haridasan M (1982) Aluminium accumulation by some cerrado native species of Central Brazil. Plant Soil 65(2):265-273. doi:10.1007/bf02374657

32. Geoghegana IE, Sprenta JI (1996) Aluminum and nutrient concentrations in species native to Central Brazil. Commun Soil Sci Plant Anal 27(18-20):2925-2934. doi:10.1080 /00103629609369752 
33. Watanabe T, Osaki M (2002) Role of organic acids in aluminum accumulation and plant growth in Melastoma malabathricum. Tree Physiol 22(11):785-792

34. Bellamy PE, Shore RF, Ardeshir D, Treweek JR, Sparks TH (2000) Road verges as habitat for small mammals in Britain. Mammal Rev 30(2):131-139. doi:10.1046/j.1365-2907.2000.00061.x

35. Yoccoz NG, Stenseth NC, Henttonen H, Prévot-Julliard A-C (2001) Effects of food addition on the seasonal density-dependent structure of bank vole Clethrionomys glareolus populations. J Anim Ecol 70(5):713-720. doi:10.1046/j.0021-8790.2001.00531.x

36. Torre I, Arrizabalaga A (2008) Habitat preferences of the bank vole Myodes glareolus in a Mediterranean mountain range. Acta Theriol (Warsz) 53(3):241-250. doi:10.1007/BF03193120

37. Moore NP, Askew N, Bishop JD (2003) Small mammals in new farm woodlands. Mammal Rev 33(1):101-104. doi:10.1046/ j.1365-2907.2003.00004.x

38. Gipps JH (1985) Spacing behaviour and male reproductive ecology in voles of the genus Clethrionomys. Ann Zool Fenn 22(3):343351

39. Ratkiewicz M, Borkowska A (2000) Multiple paternity in the bank vole (Clethrionomys glareolus): field and experimental data. Z Saugetier 65(1):6-14

40. Borkowska A, Ratkiewicz M (2010) Promiscuity, male reproductive success and mate relatedness in a natural population of the common vole. J Zool 280(2):195-201. doi:10.1111/j.14697998.2009.00648.x

41. Oksanen TA, Jonsson P, Koskela E, Mappes T (2001) Optimal allocation of reproductive effort: manipulation of offspring number and size in the bank vole. Proc R Soc A 268(1467):661-666. doi:10.1098/rspb.2000.1409

42. Martiniakova M, Omelka R, Grosskopf B, Jancova A (2010) Yellow-necked mice (Apodemus flavicollis) and bank voles (Myodes glareolus) as zoomonitors of environmental contamination at a polluted area in Slovakia. Acta Vet Scand 52:58. doi:10.1186/1751-0147-52-58

43. Murtomaa M, Tervaniemi OM, Parviainen J, Ruokojarvi P, Tuukkanen J, Viluksela M (2007) Dioxin exposure in contaminated sawmill area: the use of molar teeth and bone of bank vole (Clethrionomys glareolus) and field vole (Microtus agrestis) as biomarkers. Chemosphere 68(5):951-957. doi:10.1016/j. chemosphere.2007.01.030

44. Zakrzewska M, Sawicka-Kapusta K, Perdenia A, Wosik A (1993) Heavy metals in bank voles from Polish national parks. The Science of the Total Environment: 167-172

45. Kruczek M, Styrna J (2009) Semen quantity and quality correlate with bank vole males' social status. Behav Process 82(3):279-285. doi:10.1016/j.beproc.2009.07.009

46. Kruczek M, Zatorska M (2008) Male rank affects reproductive success and offspring performance in bank voles. Physiol Behav 94(4):611-615. doi:10.1016/j.physbeh.2008.04.016

47. Kruczek M (2007) Recognition of kin in bank voles (Clethrionomys glareolus). Physiol Behav 90(2-3):483-489. doi:10.1016/j.physbeh.2006.10.012

48. Marchlewska-Koj A, Kruczek M, Kapusta J, Pochroń E (2003) Prenatal stress affects the rate of sexual maturation and attractiveness in bank voles. Physiol Behav 79(2):305-310. doi:10.1016/ s0031-9384(03)00099-4

49. Green E (1966) Breeding systems. Biology of laboratory mouse. McGraw-Hill Book Company, New York

50. Miska-Schramm A, Kruczek M, Kapusta J (2014) Effect of copper exposure on reproductive ability in the bank vole (Myodes glareolus). Ecotoxicol 23(8):1546-1554. doi:10.1007/s10646014-1295-6

51. Kruczek M (1986) Seasonal effects on sexual maturation of male bank voles (Clethrionomys glareolus). J Reprod Fertil 76(1):83-89. doi:10.1530/jrf.0.0760083
52. Grocock CA (1979) Testis development in the vole, Microtus agrestis, subjected to long or short photoperiods from birth. J Reprod Fert 55:423-427

53. Pedersen T, Peters H (1968) Proposal for a classification of oocytes and follicles in the mouse ovary. J Reprod Fertil 17(3):555-557

54. Abdul-Rasoul EM, Hassan NA, Al-Mallah KH (2008) Effect of aluminium chloride on sexual efficiency in adult male rats. J Edu \& Sci 22(4):27-44

55. Mayyas I, Elbetieha A, Khamas W, Khamas WA (2005) Evaluation of reproductive and fertility toxic potentials of aluminum chloride on adult male mice. J Anim Vet Adv 4:224-233

56. Hichem N, May ME, Laadhari N, Mrabet A, Gharbi R (2013) Effect of chronic administration of aluminum trichloride on testis among adult albino Wistar rats. J Cytol Histol 4(5):1-4. doi:10.4172/2157-7099.1000195

57. Abu-Taweel GM, Ajarem JS, Ebaid H (2011) Aluminum-induced testosterone decrease results in physiological and behavioral changes in male mice. Afr J Biotechnol 10(2):201-208. doi:10.5897/ AJB10.517

58. Sun H, Hu C, Jia L, Zhu Y, Zhao H, Shao B, Wang N, Zhang Z, Li $Y$ (2011) Effects of aluminum exposure on serum sex hormones and androgen receptor expression in male rats. Biol Trace Elem Res 144(1-3):1050-1058. doi:10.1007/s12011-011-9098-6

59. Chinoy NJ, Sorathia HP, Ahmedabad DDJ (2005) Fluoride+aluminium induced toxicity in mice testis with giant cells and its reversal by vitamin C. Fluoride 38(2):109-114

60. Khattab F, Khattab I (2007) Histological and ultrastructural studies on the testis of rat after treatment with aluminium chloride. Aust J Basic Appl Sci 1(1):63-72

61. Mahran A, AlRashidy A, ElMawla A (2011) Role of propolis in improving male rat fertility affected with aluminum chloride cytotoxicity. Spat DD - Peer Revi J Complement Med Drug Discov 189. doi: 10.5455/spatula.20111122065544

62. Johnson L, McKenzie KS, Snell JR (1996) Partial wave in human seminiferous tubules appears to be a random occurrence. Tissue Cell 28(2):127-136. doi:10.1016/S0040-8166(96)80001-2

63. Buraimoh AA, Ojo SA, Hambolu JO, Adebisi SS (2012) Histological study of the effects of aluminium chloride exposure on the testis of Wistar rats. Aijcr 2(5):114-122

64. Shin SC, Kang YM, Jin YW, Kim HS (2009) Relative morphological abnormalities of sperm in the caudal epididymis of high- and low-dose-rate gamma-irradiated ICR mice. J Radiat Res 50(3):261266

65. Dawson EB, Ritter S, Harris WA, Evans DR, Powell LC (1998) Comparison of sperm viability with seminal plasma metal levels. Biol Trace Elem Res 64(1-3):215-219. doi:10.1007/bf02783337

66. Hovatta O, Venalainen ER, Kuusimaki L, Heikkila J, Hirvi T, Reima I (1998) Aluminium, lead and cadmium concentrations in seminal plasma and spermatozoa, and semen quality in Finnish men. Hum Reprod 13(1):115-119. doi:10.1093/humrep/13.1.115

67. Yousef MI, Kamel KI, El-Guendi MI, El-Demerdash FM (2007) An in vitro study on reproductive toxicity of aluminium chloride on rabbit sperm: the protective role of some antioxidants. Toxicol 239(3):213-223. doi:10.1016/j.tox.2007.07.011

68. McLachlan RI, O’Donnell L, Meachem SJ, Stanton PG, de Kretser DM, Pratis K, Robertson DM (2002) Identification of specific sites of hormonal regulation in spermatogenesis in rats, monkeys, and man. Recent Prog Horm Res 57:149-179

69. Guo CH, Ko WS, Chen PC, Hsu GS, Lin CY, Wang CL (2009) Alterations in trace elements and oxidative stress in uremic patients with dementia. Biol Trace Elem Res 131(1):13-24. doi:10.1007/ s12011-009-8342-9

70. Zhu YZ, Sun H, Fu Y, Wang J, Song M, Li M, Li YF, Miao LG (2014) Effects of sub-chronic aluminum chloride on spermatogenesis and testicular enzymatic activity in male rats. Life Sci 102(1): 36-40. doi:10.1016/j.lfs.2014.02.035 
71. Nayak P (2002) Aluminum: impacts and disease. Environ Res 89(2):101-115

72. Julka D, Vasishta RK, Gill KD (1996) Distribution of aluminum in different brain regions and body organs of rat. Biol Trace Elem Res 52(2):181-192. doi:10.1007/bf02789460

73. Anane R, Bonini M, Grafeille JM, Creppy EE (1995) Bioaccumulation of water soluble aluminium chloride in the hippocampus after transdermal uptake in mice. Arch Toxicol 69(8):568-571

74. Bharathi P, Vasudevaraju P, Govindaraju M, Palanisamy AP, Sambamurti K, Rao KS (2008) Molecular toxicity of aluminium in relation to neurodegeneration. Indian J Med Res 128(4):545-556

75. Verstraeten SV, Aimo L, Oteiza PI (2008) Aluminium and lead: molecular mechanisms of brain toxicity. Arch Toxicol 82(11): 789-802. doi:10.1007/s00204-008-0345-3

76. Barabasz W, Albińska D, Jaśkowska M, Lipiec J (2002) Ecotoxicology of aluminium. Pol J Environ Stud 11(3):199-203

77. Kumar S (2002) Aluminium-induced changes in the rat brain serotonin system. Food Chem Toxicol 40(12):1875-1880

78. Agency for Toxic Substances and Disease Registry; Toxicological profile for aluminum (2008).

79. Contini Mdel C, Millen N, Gonzalez M, Mahieu S (2011) Melatonin prevents oxidative stress in ovariectomized rats treated with aluminium. Biol Trace Elem Res 144(1-3):924-943. doi:10.1007/s12011-011-9060-7

80. Muselin F, Trif A, Dumitrescu E, Cimpoeș GS (2011) Body weight dynamics in rats exposed to aluminium, melatonin and Sempervivum extract. Luc Stiin - Uni Stiin Agri Banat Tim Med Vet 44(2):129-132

81. Bojkowska K, Aloisio F, Cassano M, Kapopoulou A, Santoni de Sio F, Zangger N, Offner S, Cartoni C, Thomas C, Quenneville S, Johnsson K, Trono D (2012) Liver-specific ablation of Kruppelassociated box-associated protein 1 in mice leads to malepredominant hepatosteatosis and development of liver adenoma. Hepatology 56(4):1279-1290. doi:10.1002/hep.25767

82. Waxman DJ, O'Connor C (2006) Growth hormone regulation of sex-dependent liver gene expression. Mol Endocrinol 20(11):2613 2629. doi:10.1210/me.2006-0007
83. Kalthoff S, Winkler A, Freiberg N, Manns MP, Strassburg CP (2013) Gender matters: estrogen receptor alpha (ERalpha) and histone deacetylase (HDAC) 1 and 2 control the gender-specific transcriptional regulation of human uridine diphosphate glucuronosyltransferases genes (UGT1A. J Hepatol 59(4):797804. doi:10.1016/j.jhep.2013.05.028

84. Park EJ, Lee JH, Yu GY, He G, Ali SR, Holzer RG, Osterreicher CH, Takahashi H, Karin M (2010) Dietary and genetic obesity promote liver inflammation and tumorigenesis by enhancing IL-6 and TNF expression. Cell 140(2):197-208. doi:10.1016/j. cell.2009.12.052

85. Giannitrapani L, Soresi M, La Spada E, Cervello M, D'Alessandro N, Montalto G (2006) Sex hormones and risk of liver tumor. Ann N Y Acad Sci 1089:228-236. doi:10.1196/annals.1386.044

86. Gómez M, Sanchez DJ, Llobet JM, Corbella J, Domingo JL (1996) The effect of age on aluminum retention in rats. Toxicology $116(1-$ 3): $1-8$

87. Thorne BM, Donohoe T, Lin KN, Lyon S, Medeiros DM, Weaver ML (1986) Aluminum ingestion and behavior in the Long-Evans rat. Physiol Behav 36(1):63-67

88. Cherroret G, Bernuzzi V, Desor D, Hutin MF, Burnel D, Lehr PR (1992) Effects of postnatal aluminum exposure on choline acetyltransferase activity and learning abilities in the rat. Neurotoxicol Teratol 14(4):259-264. doi:10.1016/08920362(92)90005-U

89. Lal B, Gupta A, Gupta A, Murthy RC, Ali MM, Chandra SV (1993) Aluminum ingestion alters behaviour and some neurochemicals in rats. Indian J Exp Biol 31(1):30-35

90. Santucci D, Rankin J, Laviola G, Aloe L, Alleva E (1994) Early exposure to aluminium affects eight-arm maze performance and hippocampal nerve growth factor levels in adult mice. Neurosci Lett 166(1):89-92

91. Kapusta J, Sales GD, Czuchnowski R (2007) Aggression and vocalization behaviour of three sympatric vole species during conspecific and heterospecific same-sex encounters. Behaviour 144(3): s83-305. doi:10.1163/156853907780425730 